\title{
Stonemeal of amazon soils with sediments from reservoirs: a case study of remineralization of the tucuruí degraded land for agroforest reclamation
}

\author{
SUZI H. THEODORO ${ }^{1}$, OTHON H. LEONARDOS ${ }^{1}$, EDUARDO ROCHA ${ }^{2}$, \\ IRIS MACEDO ${ }^{3}$ and KLEYSSON G. REGO ${ }^{4}$ \\ ${ }^{1}$ Universidade de Brasília/ UnB, Centro de Desenvolvimento Sustentável, \\ Campus Darcy Ribeiro, Bl. C, 70904-970 Brasília, DF, Brasil \\ ${ }^{2}$ Ipoema (Instituto de Permacultura), Caixa Postal 8024, Sudoeste, 70673-970 Brasília, DF, Brasil \\ ${ }^{3}$ Universidade de Brasília/ UnB, Departamento de Engenharia Civil e Ambiental, \\ Faculdade de Tecnologia, Campus Darcy Ribeiro, 70910-900 Brasília, DF, Brasil \\ ${ }^{4}$ FUSI (Fundação Sonia Ivar), SHS Qd 08, Conj. A, Bl. E, s. 1005, \\ Ed. Business Center Park Brasil XXI, 70316-000 Brasília, DF, Brasil
}

Manuscript received on March 1, 2012; accepted for publication on June 29, 2012

\begin{abstract}
This study suggests the employment of accumulated sediments in the reservoir of Tucuruí (Pará /Brazil) to remineralize the surrounding degraded soils. The approach was based on the principles of stonemeal technology. It suggests that the soil can be rejuvenated by crushed rocks rich in macro and micronutrients. Removal of the sediments for agricultural use will bring benefits to family farmers and increase the life cycle of the reservoir and, therefore, energy generation. Geochemical data on retained sediments, soils and rocks in the area of influence of the reservoir were evaluated regarding nutrient transport mechanisms and soil-fertility potential. Results show that sediments from the reservoir contain nutrients levels at least one order of magnitude greater than average Amazon region soils. Our data on soil use and occupation in the region show the degradation areas which could be recovered by stonemeal techniques. Thence, an Agroforestry System was installed, with 12 plots where different mixtures of sediments removed from the reservoir were used, along with crushed rock with or without the addition of NPK and manure. The experiments showed that maximum crop yield and plant growth were attained in the plots where a mixture of sediments, crushed rocks and manure were added.
\end{abstract}

Key words: geochemistry, sediments, reservoir, agroforestry, sustainable development.

\section{INTRODUCTION}

The Tucuruí reservoir is inside an Environmental Protected Area of 568,667 ha, in Pará State. Its contribution basin is formed by the Tocantins and Araguaia rivers which are widely responsible for the sediment load that reaches the Reservoir. The

Correspondence to: Suzi Huff Theodoro

E-mail: suzitheodoro@unb.br sediments drain into the Tucuruí reservoir from the states of Goiás, Tocantins, Pará, Maranhão, Mato Grosso and the Federal District (Figure 1).

Eight municipalities (Jacundá, Novo Repartimento, Itupiranga, Nova Ipixuna, Tucuruí, Marabá, Goianésia do Pará and Breu Branco) surround and impact the Tucuruí reservoir. Before the establishment of the reservoir, most of the 


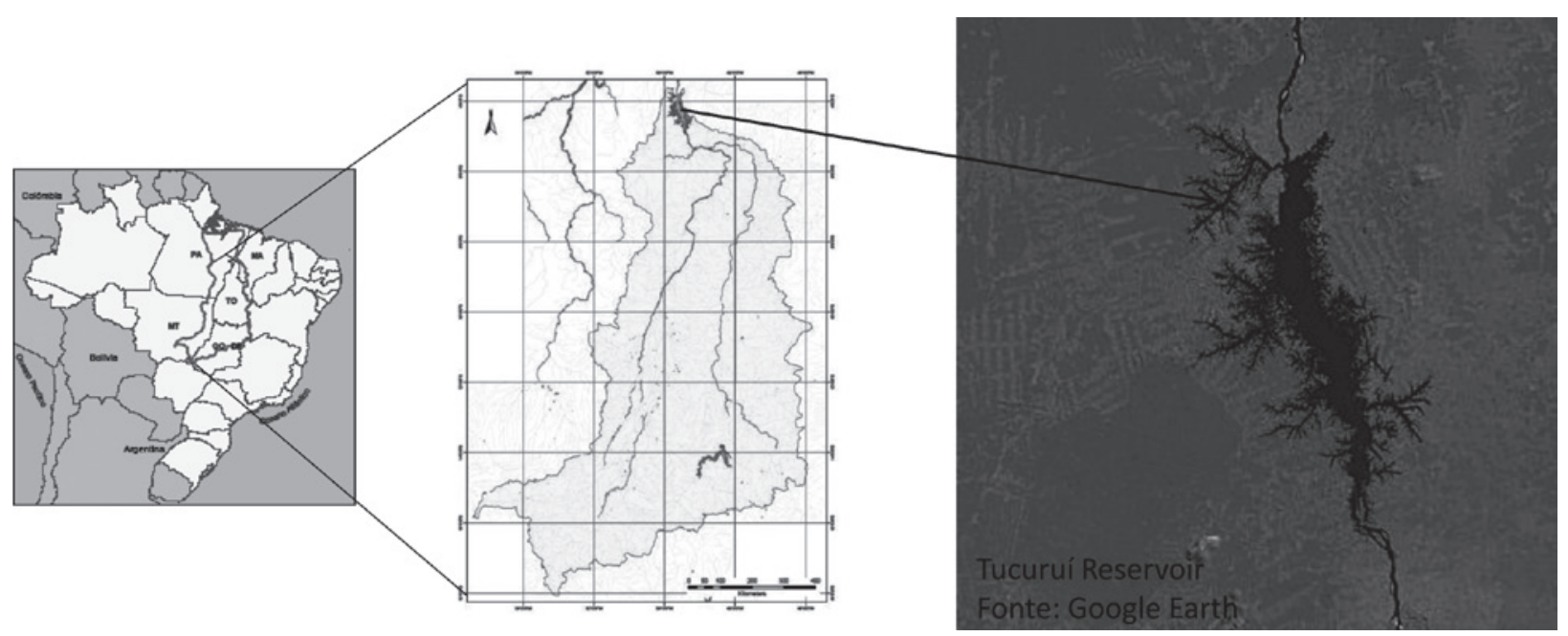

Figure 1 - Localization of the contribution basin of the Tucuruí reservoir.

Tucuruí region was covered by rainforest. Impacted by the dam construction, the region has undergone fast deforestation, land degradation and increased urbanization, which exacerbated environmental problems. The region also shows a vast diversity of rock formations from different geological environments, with distinct ages, genesis and late deformation and alteration processes. Three major geological units are present: Amazon Craton, Araguaia Belt and Parnaiba Sedimentary Basin (Tassinari and Macambira 1999). Recently CPRM (Brasil 2004) has suggested that the terrains in the left margin of the Tocantins river, formerly referred to as the Xingu complex, should be divided into four geological lithologic units: a) the Cajazeiras enderbite, chiefly formed by charnockite, enderbite and hedenbergite-kinzigite, $b$ ) the Direita granulitic suite formed by granulites and mylonites, c) the Rio Preto pyriclasite and d) the São Manoel and Misteriosa Groups formed by meta-volcanic rocks, which strike close to the dam, as highly potential materials to rejuvenate local soils. Thick epidotized flows of meta-basaltic rocks of the Tucuruí formation lie under a sequence of greywacke meta-sediments. Both belong to the Tocantins Group, which outcrop in the right margin of the Tocantins River. Sandstones and shales of the Parnaiba Paleozoic sedimentary basin are covered by Cretaceous sediments of the Itapecuru formations (Trouw et al. 1996). Deposition of the Barreiras formation in the Tertiary has also marked the widespread presence of laterites and deep leached soil cover formed under varying dry and wet climatic conditions. Latosols formed by gibbsite and/or iron oxide which varies in concentration depending on depth, and sandy to clayey kaolinitic podzolic soils are the sole soil classes in the area. Both are strongly acidic and show extremely low natural fertility due to chemical leaching, especially on the eastern reservoir margin (Theodoro et al. 2007).

In this study it was assumed that the incorporation in the soil of specific types of (crushed) rocks and/or reservoir sediments could restore primary soil fertility levels while keeping the overall geochemical balance of a natural environment (Leonardos et al. 1976, Theodoro 2000, Leonardos and Theodoro 1999). In general, mafic rocks such as meta-basalts, volcanic and plutonic rocks, or even sedimentary rocks such as marl should supply macronutrients $(\mathrm{P}, \mathrm{K}, \mathrm{Ca}$ and $\mathrm{Mg}$ ) besides a series of essential micronutrients for the plant nutrition (Leonardos et al. 2000, Theodoro and Leonardos 2006). Later, Fonseca et al. 2007 and Theodoro et al. 2007 have shown that alluvial sediments 
accumulated in reservoirs, such as silt, clays and organic matter, deltas or flood plains, act as soil rejuvenators, being a potential material to be used in tropical agriculture. The alluvial sediments represent the sum of a wide variety of bedrocks with different nutrient combinations from a diverse geological environment.

\section{MATERIALS AND METHODS}

To study the potential use of the accumulated sediments in the Tucuruí Reservoir as fertilizer, the following steps were carried out: (1) Reservoir geospatial configuration study including - geology, pedology, soil use, landscape and soil erosibility; (2) Establishment of a sampling grid of reservoir surrounding soils (15 points) and retained sediments georeferenced in the reservoir (20 points); (3) Sample collection of deep sediment using a simple dredge ot the Shipeck type. Sampling was carried out in two distinct periods, soon after the rainy season (April), and soon after the dry season (November). All samples were dried at $40^{\circ} \mathrm{C}$ to loose excess water; (4) Soil and rock samples were collected from various representative points from different geological formations; (5) Bulk-chemical analyses of major $\left(\mathrm{SiO}_{2}, \mathrm{TiO}_{2}, \mathrm{Al}_{2} \mathrm{O}_{3}\right.$, $\mathrm{Fe}_{2} \mathrm{O}_{3}, \mathrm{MgO}, \mathrm{CaO}$, and $\left.\mathrm{K}_{2} \mathrm{O}\right)$, minor $\left(\mathrm{P}_{2} \mathrm{O}_{5}\right.$ and $\left.\mathrm{MnO}\right)$ and trace elements $(\mathrm{Ba}, \mathrm{Rb}, \mathrm{Sr}, \mathrm{Ta}, \mathrm{Nb}, \mathrm{Y}, \mathrm{Ga}, \mathrm{Zr}$, Th, Hf, U, V, Co, W, Be, Cs, Cu, Pb and $\mathrm{Zn}$ ) were carried out from both sediments and soils; the major element oxides were analyzed by Plasma Atomic Emission Spectrophotometry and Atomic Emission by Inductive Coupled Plasma Spectrophotometry at the Bondar-Clegg Laboratories, Canada. The statistical analyses were made using SPSS program (version 15.0). Standard fertility analysis (Mehlich extraction with $\mathrm{HCl} 0.05 \mathrm{M}+\mathrm{H}_{2} \mathrm{SO}_{4} 0,0125 M$ ) was carried out by CAMPO Laboratory. The $\mathrm{pH}\left(\mathrm{H}_{2} \mathrm{O}\right)$ and $\mathrm{pH}\left(\mathrm{CaCl}_{2}\right)$ were measured by a $\mathrm{pH}$ meter and organic matter content by calorimetric method; (6) Grain size, porosity and permeability determinations of the sediments and soils were also made as to find the more efficient soil-rock-sediment mixes to provide good drainage and aeration for the plant's root system; (7) Diagrams of major, minor and trace-element (including the highly toxic chemical elements, $\mathrm{Hg}$, $\mathrm{Pb}, \mathrm{Cd}, \mathrm{As}, \mathrm{Cl}, \mathrm{Ni}, \mathrm{Ba}$ and $\mathrm{Sr}$ ) contents in the reservoir sediments and in surrounding soils were plotted, with reference to classical data for Amazon soils and crustal average; (8) Sediment samples were analyzed at different intervals of water lamina to evaluate the continuous circulation of chemical elements through the sediment-water interface; (9) Experiments were set up to study the agronomic response to the application of different sediments, rocks and soils proportions in an Agroforestry System. The field tests were carried out, using a mix of sediments, crushed rocks and manure in different proportions to evaluate its effect on plant development and soil fertility; (10) The Agroforestry System covered an area of $675 \mathrm{~m}^{2}$, cultivated with native forest species, leguminous and agricultural plants and it was divided into 12 parcels that received three different treatments $(\mathbf{T} 1, \mathbf{T} 2$ and T3), three different plant density (B1, B2 and B3) and three repetitions. Each parcel was separated by trenches $30 \mathrm{~cm}$ wide and $30 \mathrm{~cm}$ deep to avoid contamination among the different treatments; (11) Natural soil control parcel with three repetitions (T0) where also installed. In the treatments, 30 $\mathrm{kg}$ of sediments and $30 \mathrm{~kg}$ of rock dust (half of it applied along 4 lines and half placed inside the soil holes. In the $\mathbf{T} 1$ parcel, this was the sole addition, in the T2 parcel, $3 \mathrm{~kg}$ of NPK (10:10:10) was additionally placed and in the $\mathbf{T} 3$ parcel, 120 $\mathrm{kg}$ of manure was incorporated. In all, 104 forest seedlings from 17 species of the Amazon biome were planted; and (12) their height evaluated along with the changing soil-fertility ${ }^{1}$.

\footnotetext{
${ }^{1}$ The fertility analysis was made using two types of extractors (Citric acid $2 \%$ and extraction solution Mehlich - I $0.05 \mathrm{Cl}+0.0125 \mathrm{M} \mathrm{H} \mathrm{H}_{2} \mathrm{SO}_{4}$.
} 


\section{RESULTS}

\section{CHEMICAL CHARACTERIZATION OF MATERIALS}

This research found that the sediments retained in the reservoir were enriched with macronutrients such as $\mathrm{Ca}, \mathrm{Mg}, \mathrm{K}, \mathrm{P}$ and $\mathrm{S}$ up to one degree magnitude. Micronutrients such as $\mathrm{B}, \mathrm{Cr}, \mathrm{Cu}$ and $\mathrm{Co}$ were also observed in larger quantities when compared to the lateritic soils (oxisols) of the surrounding region, or with other soils in the Amazon region, which were intensely impoverished in relation to the matrix rocks or to the average crust composition. The chemical characterization of some available rocks in the region (e.g. phyllite and carbonate marl) showed an aptitude to be complementary to the chemistry of the retained sediments, being appropriate to form a "mix" with them to be used as stonemeal, with an additional advantage for being available as finely crushed materials in a nearby quarry. The phyllite is composed of carbonate, epidote and minor quartz in a micritic matrix of plagioclase, amphibole, mica and K-feldspar. Such rock-forming mineral compositions points to a wide balanced chemical element spectra that render themselves for agricultural use. The phyllite fertility analysis used in the experiment reveals significant contents of nutrients $\mathrm{CaO}$ (1.96\%), $\mathrm{MgO}$ (1.53\%), $\mathrm{P}_{2} \mathrm{O}_{5}(0.22 \%)$ and $\mathrm{K}_{2} \mathrm{O}(0.32 \%)$.

In the variation diagrams shown up ahead, the retained geochemical sediment data from two sampling surveys are compared with data from surrounding soils and from Amazon reference soils reported in the pioneer work of Kronberg et al. 1987. The more insoluble group of oxides showed $\left(\mathrm{SiO}_{2}, \mathrm{Fe}_{2} \mathrm{O}_{3}\right.$ and $\left.\mathrm{Al}_{2} \mathrm{O}_{3}\right)$ clearly defined concentration trends. $\mathrm{SiO}_{2}$ shows a strong upstream concentration, while $\mathrm{Fe}_{2} \mathrm{O}_{3}$ and $\mathrm{Al}_{2} \mathrm{O}_{3}$ present a moderate downstream concentration towards the dam. As has been already mentioned by Fonseca et al. 2007, and confirmed in the present research, silica and aluminum have large influence in the Reservoir sedimentation, showing a distinctive correlation those points to different genesis. Iron presents low values and uniform behavior with a tendency to show upstream lower values close to the reservoir entrance. $\mathrm{P}_{2} \mathrm{O}_{5}$ is present in small amounts having a similar behavior to $\mathrm{Fe}_{2} \mathrm{O}_{3}$, showing downstream concentrations. $\mathrm{K}_{2} \mathrm{O}, \mathrm{CaO}$ and $\mathrm{MgO}$, though in low concentrations, are extremely enriched in relation to the local soils. Potassium, a fundamental component of fertile soils, shows relatively uniform behavior in both sampling periods. Samples collected closer to the old canyon of the Tocantins River are richer in potassium than elsewhere, probably being derived from the weathering of feldspar and mica in the volcanic rocks of Marabá. As expected, calcium and magnesium are dissolved during river transport and show higher upstream values.

The marked concentration of silicon, iron and aluminum oxides in the soils in contrast with the low concentrations of calcium, potassium and magnesium reinforces the fact these are well leached lateritic soils. Enriched towards the dam, following stationary iron and aluminum, but also associated with high concentrations of organic matter (up to $20 \%$ ), phosphorus seems to be associated with iron and aluminum in the crystalline structure of clays and in the organic compounds. In Table I and Figure 2 diagrams the first value is the reference value for terrestrial crust which is followed by a sequence labeled $\mathrm{Fa}$, representing values for the Amazon soils described by Kronberg et al. 1987. The third sequence, labeled TUC, represents concentration values for sediments collected during the first campaign (rainy period). The fourth sequence represents the same points in the reservoir in the dry season. In the last sequence, on the right of the diagrams, labeled TUCs are the oxide values for the soils surrounding the reservoir. Phosphorus (Figure 2a) shows greater concentrations in the sediments than in the soils. Potassium (Figure 2b) shows a more remarkable difference in relation to the two soil groups. Such characteristics enhance the potentiality of the retained sediments to fertilize local soils. 
TABLE I

Concentration of $\mathrm{CaO}, \mathrm{K}_{2} \mathrm{O}, \mathrm{P}_{2} \mathrm{O}_{5}$ and $\mathrm{MgO}$ in the soils and in the sediments

* Sediments sample groups from the second period of collect.

\begin{tabular}{|c|c|c|c|c|c|c|c|c|c|}
\hline Sample & $\mathbf{C a O}$ & $\mathbf{K}_{\mathbf{2}} \mathbf{O}$ & $\mathbf{P}_{\mathbf{2}} \mathbf{O}_{\mathbf{5}}$ & $\mathbf{M g O}$ & Sample & $\mathbf{C a O}$ & $\mathbf{K}_{\mathbf{2}} \mathbf{O}$ & $\mathbf{P}_{\mathbf{2}} \mathbf{O}_{\mathbf{5}}$ & $\mathbf{M g O}$ \\
\hline Crust* & & 2.22 & 0.25 & & Tuc 1 & 0.05 & 0.33 & 0.15 & 0.2 \\
\hline FA1 & 0.003 & 0.02 & 0.1 & 0.02 & Tuc 2 & 0.09 & 0.51 & 0.37 & 0.27 \\
\hline FA5 & 0.003 & 0.03 & 0.15 & 0.04 & Tuc 3 & 0.14 & 1.96 & 0.35 & 0.87 \\
\hline FA7 & 0.04 & 0.16 & 0.004 & 0.01 & Tuc 5A & 0.14 & 2.36 & 0.23 & 1.03 \\
\hline FA9 & 0.003 & 0.02 & 0.06 & 0.02 & Tuc 7 & 0.14 & 1.8 & 0.41 & 0.84 \\
\hline FA11 & 0.005 & 0.18 & 0.03 & 0.05 & Tuc 8 & 0.13 & 1.89 & 0.44 & 0.10 \\
\hline FA13 & 0.02 & 0.29 & 0.05 & 0.12 & Tuc 11 & 0.13 & 1.89 & 0.38 & 0.12 \\
\hline FA14 & 0.01 & 0.17 & 0.02 & 0.06 & Tuc 13 & 0.13 & 2.2 & 0.23 & 0.96 \\
\hline Tucs 1A & 0.13 & 0.02 & 0.32 & 0.05 & Tuc 17 & 0.22 & 1.78 & 0.13 & 0.63 \\
\hline Tucs 2 & 0.08 & 0.09 & 0.36 & 0.07 & Tuc 19 & 0.39 & 1.84 & 0.13 & 0.72 \\
\hline Tucs 4 & 0.05 & 0.25 & 0.06 & 0.05 & Tuc 1* & 0.06 & 1.85 & 0.21 & 0.33 \\
\hline Tucs 6 & 0.06 & 0.07 & -- & 0.05 & Tuc 2* & 0.10 & 0.46 & 0.46 & 0.17 \\
\hline Tucs 7B & 0.01 & 0.04 & 0.07 & 0.08 & Tuc 3* & 0.13 & 1.87 & 0.4 & 0.86 \\
\hline Tucs 9 & 0.05 & 0.14 & 0.04 & 0.04 & Tuc 5A* & 0.12 & 1.91 & 0.42 & 0.89 \\
\hline Tucs 11 & 0.07 & 0.01 & 0.03 & 0.03 & Tuc 7* & 0.18 & 2.34 & 0.22 & 0.99 \\
\hline Tucs 12B & 0.07 & 0.07 & 0.07 & 0.05 & Tuc 8* & 0.14 & 2.09 & 0.3 & 0.93 \\
\hline Tucs 14 & 0.05 & 0.01 & 0.02 & 0.03 & Tuc 11* & 0.19 & 2.53 & 0.24 & 1.07 \\
\hline Tucs 15a & 0.12 & 0.22 & 0.04 & 0.14 & Tuc 13* & 0.19 & 1.88 & 0.34 & 0.84 \\
\hline & & & & & Tuc 17* & 0.35 & 1.82 & 0.15 & 0.70 \\
\hline & & & & & Tuc 19* & 0.20 & 1.86 & 0.12 & 0.70 \\
\hline
\end{tabular}

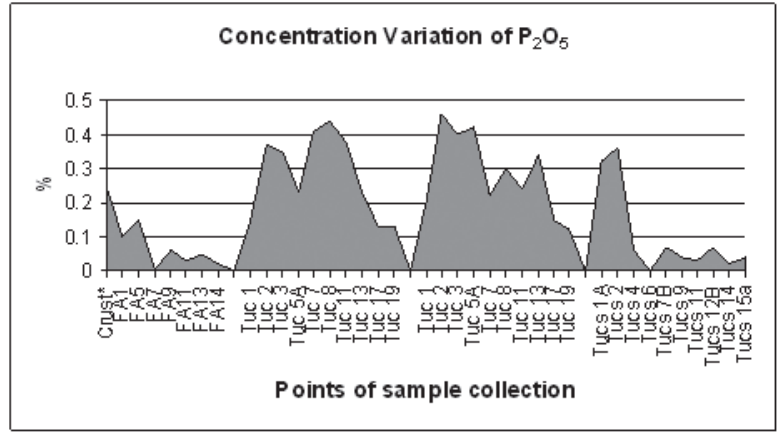

Figure 2a - Diagram showing $\mathrm{P}_{2} \mathrm{O}_{5}$ concentrations (in\%).

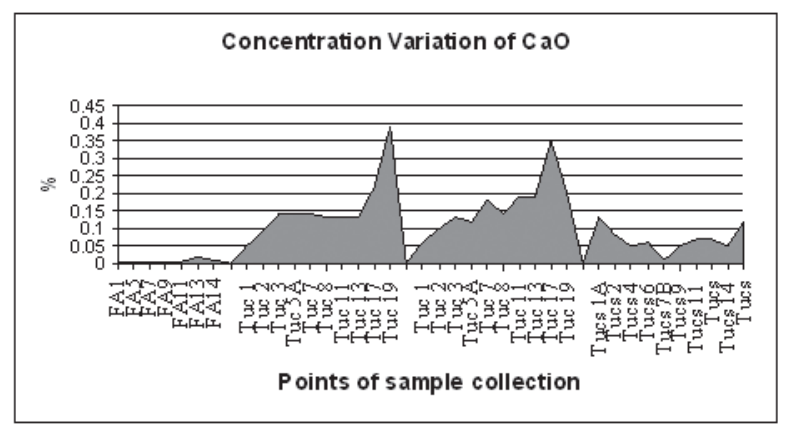

Figure 2c-Diagram showing $\mathrm{CaO}$ concentrations (in\%).

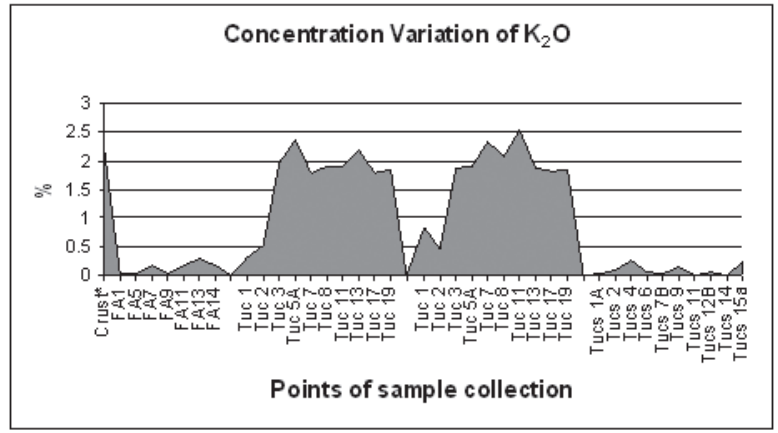

Figure $2 \mathrm{~b}$ - Diagram showing $\mathrm{K}_{2} \mathrm{O}$ concentrations (in\%).

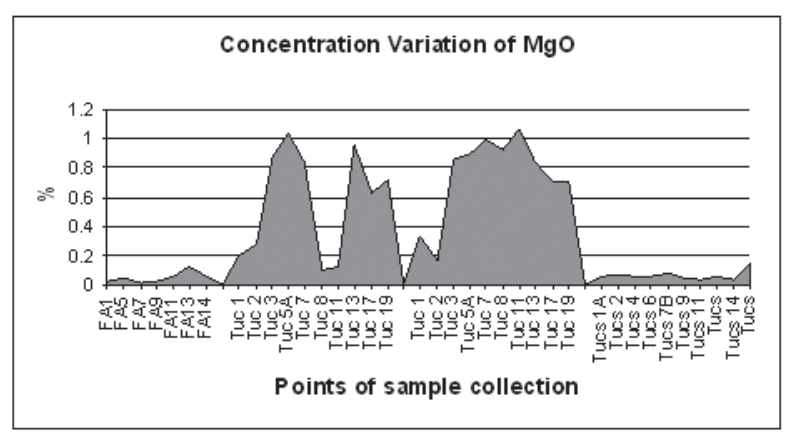

Figure 2d - Diagram showing MgO concentrations (in\%).

Figure 2 - The diagrams show the concentration of $\mathrm{P}_{2} \mathrm{O}_{5}(\mathrm{a}), \mathrm{K}_{2} \mathrm{O}$ (b), $\mathrm{CaO}$ (c) and $\mathrm{MgO}$ (d). The observed values to the left refer to the average values of the terrestrial crust (Crust*) and (FA samples), taken from Kronberg et al. 1987. Following there are the sediments sample groups from the first and second sampling periods. The last group refers to soil samples from the reservoir surrounding. 
In the same way, calcium and magnesium values in the sediments are significantly superior to those found in both soil groups (Figures $2 \mathrm{c}$ and 2d). The micronutrients boron, cobalt, copper and zinc also show relatively higher concentrations in the sediments when compared with values of either soils groups or the average crust. Mehlich extraction fertility analyses have also shown much greater $\mathrm{P}$ and $\mathrm{K}$ values in the sediments than in the local soils. The organic matter in the sediment has shown considerably higher values (11.4\% to $19 \%)$ when compared with the surrounding soils (Table II).

TABLE II

Fertility analysis of soils and sediments (two periods).

* Samples (Tucs) represent soils; (Tuc) first period of sampling and (Tuc*) second period of sampling.

\begin{tabular}{|c|c|c|c|c|c|c|c|c|c|}
\hline SAMPLES & Tucs 01b & Tucs 05 & Tucs $15 b$ & Tucs 02b & Tucs 04 & Tucs 16 & Tuc 02b* & Tuc 04* & Tuc 16* \\
\hline pH (water) & 4.2 & 5.4 & 4.1 & 4.8 & 5.2 & 4.6 & 4.8 & 5.0 & 5.5 \\
\hline pH CaCl & 3.8 & 4.2 & 3.8 & 4.3 & 4.3 & 4.2 & 4.3 & 4.1 & 4.7 \\
\hline M.O \% & 4.3 & 0.6 & 1.6 & 2.7 & 11.4 & 2.7 & 5.8 & 5.1 & 3.6 \\
\hline $\mathrm{P} \mathrm{mg} / \mathrm{dm}^{3}$ & 4.8 & 1.3 & 3.4 & 17.6 & 23.1 & 12.3 & 17.6 & 8.4 & 10.7 \\
\hline $\mathrm{S} \mathrm{mg/ \textrm {dm } ^ { 3 }}$ & 16.4 & 15.7 & 11.8 & 16.7 & 15.8 & 9.0 & 16.7 & 16.8 & 10.9 \\
\hline 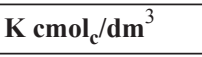 & 42 & 22 & 3.4 & 25 & 63 & 70 & 25 & 48 & 61 \\
\hline Ca cmol ${ }_{\mathbf{c}} / \mathrm{dm}^{3}$ & 0.2 & 0.1 & 0.4 & 2.4 & 2.6 & 4.6 & 0.1 & 2.8 & 5.6 \\
\hline $\mathrm{Mg} \mathrm{cmol}_{\mathrm{c}} / \mathrm{dm}^{3}$ & 0.2 & 0.2 & 0.4 & 0.3 & 0.8 & 1.4 & 0.7 & 0.8 & 1.8 \\
\hline $\mathrm{CTC}_{\mathbf{t}} \mathrm{cmol}_{\mathbf{c}} / \mathrm{dm}^{3}$ & 11.1 & 3.0 & 5.1 & 8.3 & 14 & 12 & 8.3 & 10.9 & 7.1 \\
\hline V\% & 5 & 13 & 20 & 14 & 26 & 31 & 38 & 14.6 & 14.7 \\
\hline M \% & 71 & 69 & 44 & 9 & 27 & 14 & 9 & 25 & 52 \\
\hline B ppm & 0.1 & 0.1 & 0.3 & 0.6 & 0.4 & 0.4 & 0.2 & 0.3 & 0.3 \\
\hline Zn ppm & 0.4 & 0.3 & 0.2 & 7.6 & 9.1 & 9.4 & 7.6 & 7.7 & 6.4 \\
\hline Fe ppm & 426 & 104 & 300 & 415 & 4017 & 3002 & 2273 & 3072 & 3015 \\
\hline Mn ppm & 16.2 & 1.8 & 3.3 & 231 & 541 & 180.1 & 137.6 & 56.9 & 180.1 \\
\hline Cu ppm & 0.5 & 0.3 & 0.4 & 0.6 & 5.6 & 4.9 & 4.6 & 1.5 & 0.4 \\
\hline
\end{tabular}

\section{EROSION IN THE RESERVOIR SURROUNDINGS}

Erosion is the last step prior to sediment transportation. Thus, the knowledge of the erosive processes that takes place in the reservoir, in the capture basin or in parts of it is essential for the understanding of the generation and movement phenomenon of the sediments in the basin. To characterize the erosion phenomenon, it is necessary to know the main attributes of the basin which interferes with the erosive processes dynamics, such as the soil type and coverage, geology, geomorphology, topography, precipitation regimen and the adopted conservation practices. Water erosion is a serious problem for tropical soils, especially in areas that are used for farming and livestock. Erosion reduces the productive capacity of the soil due to the transport or hauling of soil particles with nutrients and agrochemicals, which can cause a shortage of quality water due to contamination (Merten et al. 1995). The use of soil loss forecast models can furnish predictions for different uses. Data related to the physical and anthropic (geology, pedology, topography, geomorphology, climate and soil usage) factors were obtained by different cartographic products and field visits. For the identification of the areas susceptible to laminar erosion, the qualitative model presented by the IPT (1990) and the Universal Equation of Soil Loss (EUPS) presented by Mayer and Wischmeier (1969) were used. To 
identify areas susceptible to linear erosion, the qualitative model developed by Campangnoli (2002) was used. Preferred areas for laminar and linear erosion were identified, indicating sensible areas where measures mitigated erosive potential could be suggested.

The following conclusions were reached: the Tucuruí reservoir influence region presents low potential for laminar erosion in $74.8 \%$ of the area, due to the preservation measures and/or the presence of native vegetation. Medium and high potential areas for laminar erosion (25.2\%) lie very close to the reservoir, silting out and jeopardizing the soil fertile layer. Linear erosion presents low potential in $90.3 \%$ of the area, while the restricted areas of medium and high potential may cause serious damage as they rapidly develop strong collapses by ground waters, liberating vast amount of sediments (Macêdo et al. 2007). A map indicating priority areas for immediate mitigation measures was produced to encourage actions that would lead towards a more sustainable land use and greater protection of the reservoir. For that, the main criteria used were the distance of such areas in relation to the reservoir and to the Tocantins River; the distance from the urban centers and/or provincial roads areas that border the reservoir, and the distance of the areas in relation to the identified linear erosions features in the field. Out of the 37 areas identified with a high erosive or priority potential for intervention, five were selected, which need urgent measures for recuperation (Figure 4). Out of these five selected areas, it can be stated that areas 1 and 5 are the most fragile and need immediate action, since they can jeopardize the energy generation in the shortterm, as these areas are near the turbines foundations (A1) or due to easier water access to the reservoir (A5). Solution for the erosion problems do not depend on isolated actions. A plan for land use, soil and water conservation measures should move forward as an environmental management measure. Adequate vegetative cover assumes fundamental importance for declining the rain impact and the reduction of the water flow, allowing better infiltration and diminishing particle hauling. For the purpose of demonstrating the effect of the mitigating and sustainable measures, an Experimental Unit was established in Area 1, based on Agroforestry Systems (SAF) (see Figure 3). A mix of sediments was withdrawn from a point in the reservoir, crushed rocks and manure were used to improve the soil fertility conditions as well as to demonstrate the feasibility of the use of the sediments as an agricultural input.

\section{FOREST RECLAMATION}

Following elementary principles of agroecology an agroforestry system that met the research objectives was established using complex and bio-diverse intercropping to reduce yield losses by pathogens and using different capable of promoting their own nutrient supply (Rocha and Theodoro 2006). Based on this assumption, the choice of a diversified system was made, similar to what happens at the Amazon forest, in order to evaluate the potential of the Tucuruí retained sediments as cheap local material to improve soil fertility and recuperate degraded areas by anthropic activities. Following the succession concept applied to the agroforestry development, it was established a succession model based on the original local ecosystems. Knowing the geochemistry of the sediments and rocks as well as the soil nutritional restrictions, it can be assumed that the addition of these materials may help a fast regeneration of the forest system at low costs. The previous chemical knowledge of the soil and the local materials (sediments, crushed rocks and organic compounds), as well as their fertility potential allows a temporal comparison of the results obtained throughout in the different parcels. Fertility evaluation took into account $\mathrm{pH}$ variation and, phosphorus, potassium calcium, magnesium and aluminum contents. Figure 4 shows the distribution of the mixtures (sediments, rocks, NPK and organic compost), the densities of forestry species in the different parcels, the distribution of the agricultural and leguminous species. 


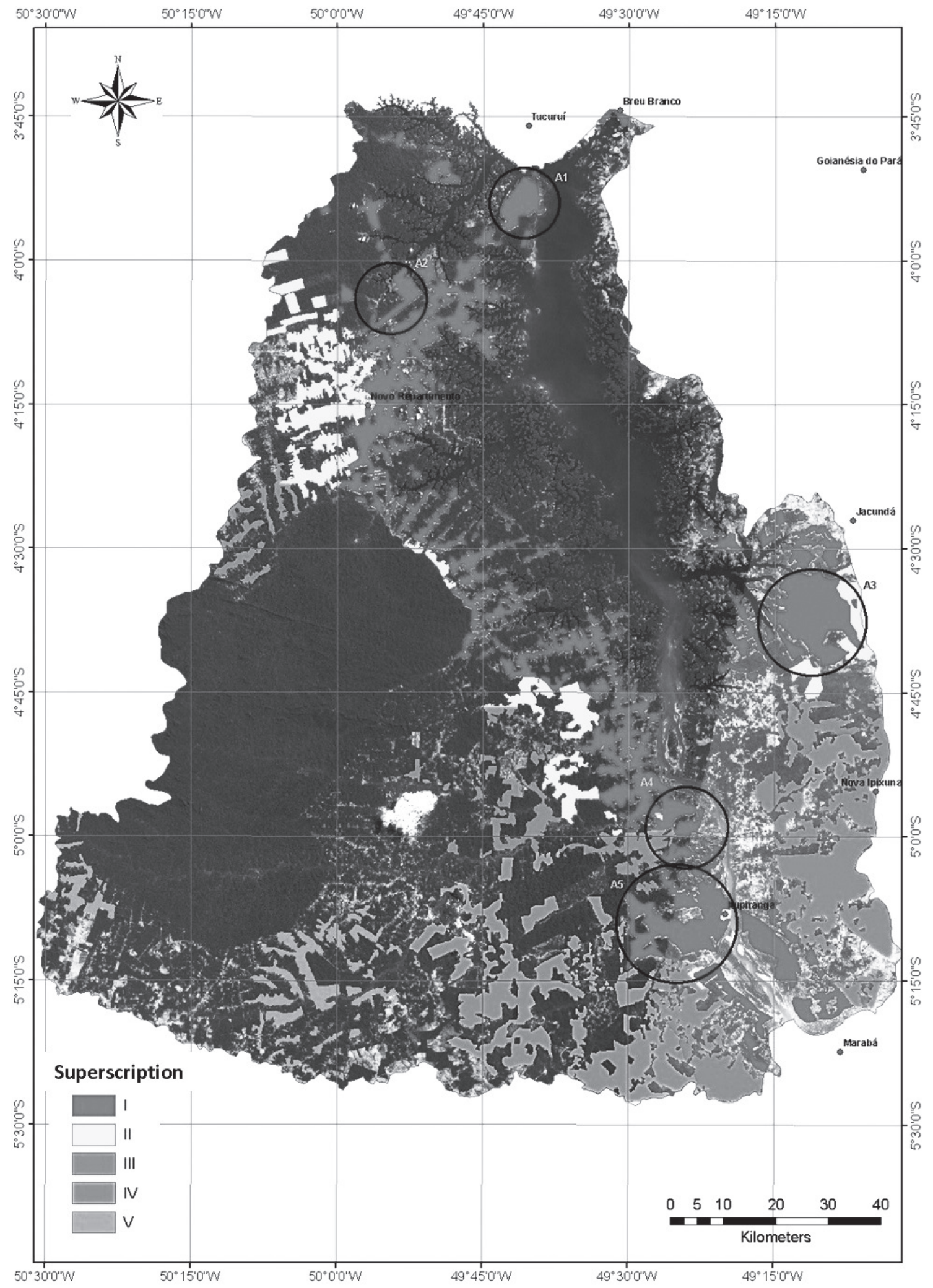

Figure 3 - Priority areas for the establishment of sustainable use measures and sample location. 


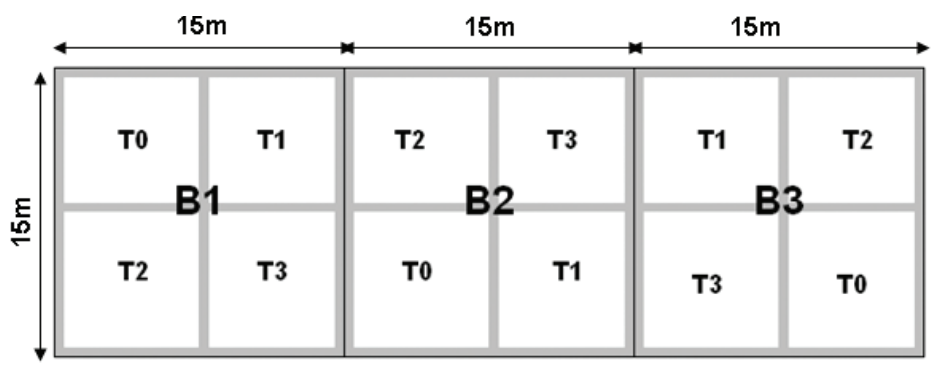

\begin{tabular}{|l|l|l|l|l|}
\hline COP & Copaíba & & PP & Pau Preto \\
\cline { 1 - 1 } JEN & Jenipapo & PAR & Parica \\
\cline { 1 - 1 } SAB & Sabonete & TAM & Tamboril \\
\cline { 1 - 1 } ANG & Angico & BAC & Bacaba \\
\hline CAl & Cacau manso & JUC & Jucá \\
\hline CA2 & Cacau bravo & AND & Andiroba \\
\hline MOG & Mogno & CUM & Cumarú \\
\hline ING & Ingá & CUP & Cupuaçú \\
\hline
\end{tabular}
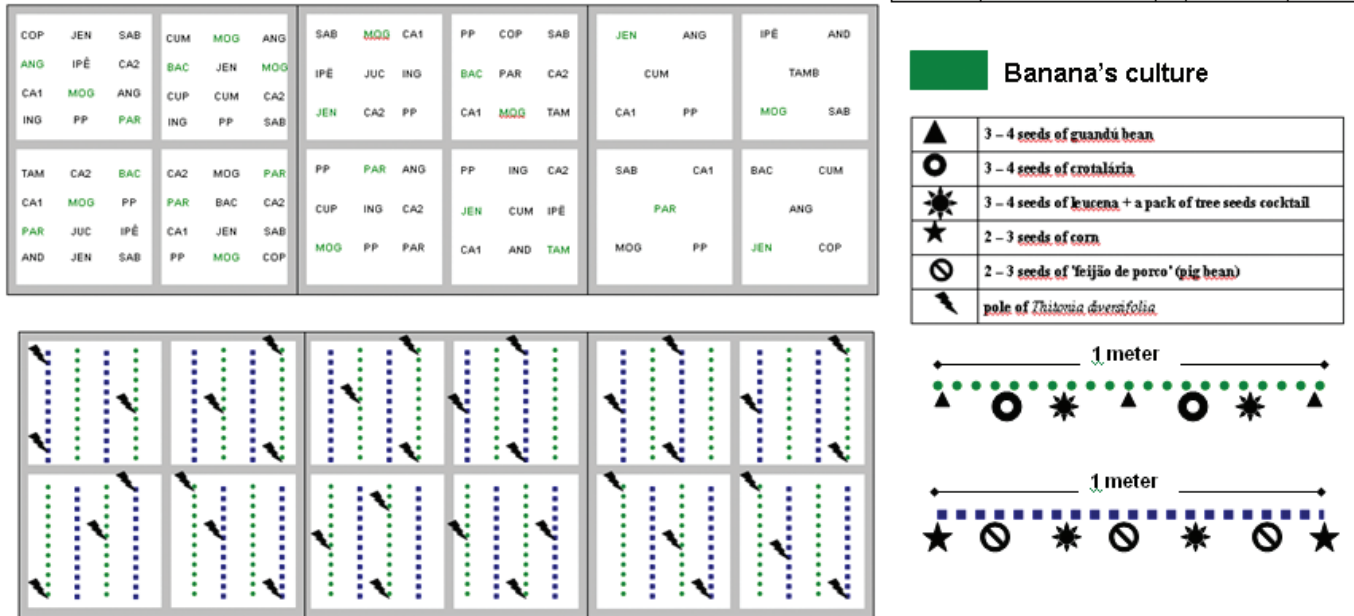

Figure 4 - SAF's Design (fertilizers mixtures' distribution, density of forestry species in the different blocks according to the density and distribution of the agricultural and leguminous species).

At the forestry nursery, vegetable seedlings (okra, pumpkin, etc) were planted in rows, along with one short-cycle agricultural species, corn (Zea maes). Leguminous plants, jack-beans, guandu beans, leucena and crotalaria were planted in rows with forestry species (Figure 4).

Throughout the Agroforestry System (SAF) follow-up period, many gauging mechanisms for the species development were done as followed: (1) monthly photographic record; (2) tree growth rate was measured periodically; (3) tree sprout counting, from the seeds cocktail; (4) corn weight measurement and vegetable yield of each treatments; (5) soil sampling and fertility analysis from the different treatments and density distribution.

The SAF development was evaluated and changes that occurred in the soil characteristics throughout this period were recorded. The T3 parcels' soils (sediments + rock + manure mix) reveal the highest macronutrient increase. Potassium values increased three times (from 42 to $145 \mathrm{ppm}$ ) in relation to the soil prior to the experiment (Table III). Calcium and magnesium increased (from 0.2 to 16 and 0.2 to $15 \mathrm{cmol}_{\mathrm{c}} / \mathrm{dm}^{3}$ respectively) in the soil, improving the $\mathrm{pH}$ conditions in all blocks (4.2 up to 6.2).

There were no significant changes in relation to the phosphorus in regards to the three density modalities. It was possible to verify that Block 1 (B1), of higher density showed an average endurance rate of $60 \%$ of the species; Block 2 (B2), a rate of $64 \%$; and, Block 3 (B3), of lower density, showed the lowest endurance rate $(50 \%)^{2}$. The arboreous species presented better performance in the blocks with a higher planting density, as well a faster growth rate and initial development. The best result for the shortcycle culture was obtained in the blocks of lower

\footnotetext{
${ }^{2}$ Borders effect could have influenced the development in Block B2's (intermediate position).
} 
TABLE III

Parcels fertility tenors at blocs B1, B2 and B3 after one year.

\begin{tabular}{|c|c|c|c|c|c|c|}
\hline & pH & Organic material (\%) & $\mathbf{P}(\mathbf{p p m})$ & $\mathrm{K}(\mathrm{ppm})$ & $\mathrm{Ca}\left(\mathrm{cmol}_{\mathrm{c}} / \mathrm{dm}^{3}\right)$ & $\mathrm{Mg}\left(\mathrm{cmol}_{\mathrm{c}} / \mathrm{dm}^{3}\right)$ \\
\hline SOIL & 4.2 & 0.7 & 3.2 & 42 & 0.2 & 0.2 \\
\hline B1T0 & 6.2 & 1.9 & 3.1 & 60 & 8.8 & 6.0 \\
\hline B1T1 & 6.2 & 1.3 & 2.0 & 111 & 7.6 & 7.3 \\
\hline B1T2 & 5.8 & 1.9 & 3.5 & 72 & 8.1 & 7.0 \\
\hline B1T3 & 6.2 & 4.1 & 5.7 & 145 & 7.7 & 4.7 \\
\hline B2T0 & 5.8 & 1.4 & 1.8 & 90 & 6.6 & 4.6 \\
\hline B2T1 & 5.9 & 1.4 & 3.0 & 105 & 8.4 & 6.3 \\
\hline $\mathrm{B} 2 \mathrm{~T} 2$ & 5.4 & 2.0 & 7.7 & 49 & 5.0 & 3.8 \\
\hline B2T3 & 5.8 & 4.5 & 12.9 & 84 & 9.0 & 6.6 \\
\hline B3T0 & 6.1 & 1.9 & 2.5 & 84 & 16.7 & 15.6 \\
\hline B3T1 & 6.1 & 1.0 & 2.3 & 46 & 8.8 & 8.0 \\
\hline B3T2 & 6.1 & 1.4 & 2.5 & 64 & 14.7 & 14.7 \\
\hline B3T3 & 5.6 & 2.7 & 3.5 & 114 & 8.9 & 7.2 \\
\hline
\end{tabular}

density (B3) ${ }^{3}$. Paricá (Schizolobium sp.), one of the species with better growth index, showed the higher rates in the blocks that received organo-mineral fertilization (B1-T3, B2-T3 and B3-T3) regardless the density. The arboreous species endurance rate was approximately $60 \%{ }^{4}$. There was a high sprouting rate of the seed cocktail ${ }^{5}$ and surprisingly, a high sprouting rate of exotic species mango (Manguifera sp.) and castanhola (Terminalia sp.) etc ${ }^{6}$. A large diversity of insects and birds that used the Experimental Unit was also observed due to the flowering of the leguminous species and the presence of the Thitonia diversifolia? The later was planted to form a protective barrier and serve as an additional source of nitrogen and organic phosphorus (van Straaten 2007).

\section{CONCLUSIONS}

From the above data we can conclude that: (1) the amount of macronutrients in the sediment samples from the reservoir were greater than in the soils; (2) concentrations of insoluble oxides $\left(\mathrm{SiO}_{2}, \mathrm{Al}_{2} \mathrm{O}_{3}\right.$ and $\mathrm{Fe}_{2} \mathrm{O}_{3}$ ) were similar to those found in the soils surrounding the reservoir; (3) the dam promoted a re-concentration of these elements at the bottom of the lake; (4) the phosphorus distribution is correlated with the distribution of iron and aluminum, suggesting that geochemical affinity is maintained in both soil and sediment; (5) soluble macronutrients like $\mathrm{P}, \mathrm{K}, \mathrm{Ca}$ and $\mathrm{Mg}$, though with low values in the reservoir sediments, show a one degree of magnitude enrichment in respect to the

\footnotetext{
${ }^{3}$ The rapid growth species requires high luminosity for its development and production.

${ }^{4}$ Four species jenipapo (Jenipa sp.), ipê (Tabebuia sp.), paricá (Schizolobium sp) and jucá (Caesalpinia sp.) had an endurance rate equal to 100\%. Angico (Anadenanthera sp.) and pau-preto (Schinopsis sp.) exceeded the $80 \%$ mark. The Cacau (Theobroma sp.), cumarú (Dipteryx sp.) and bacaba (Oenocarpus sp.) had very low endurance rates (30\%). Other three species (cupuaçu -Theobroma sp., o tamboril - Enterolobium sp. and andiroba - Carapa sp.) did not endure after a year of follow-up.

${ }^{5}$ Species such as paricá (Schizolobium sp), angico (Anadenanthera sp.) and ipê (Tabebuia sp.), (from seeds cocktail) already present sizes up to $30 \mathrm{~cm}$, demonstrating that the future SAF densification is guaranteed.

${ }^{6}$ Such species sprout from seeds that arrived at the SAF through the organic matter coverage, introduced to protect the soil until the short cycle species reached a sufficient size to protect the soil and produce shadow for the forestry species.

${ }^{7}$ Thithonia has been used in many tropical countries as an alternative source to improve the phosphorus availability in acidic and bleached soils, as is the case of the soils in the Reservoir's surrounding region.
} 
surrounding soils, making the reservoir sediment a potential soil remineralizer; (6) strong organic matter enrichment also favors its agricultural use; (7) addition of powdered carbonate phyllite from nearby quarry acts as an additional source of $\mathrm{CaO}$ and $\mathrm{MgO}$, besides improving the permeability of the mix; (8) areas close to the dam and to the southern end of the reservoir show erosion vulnerability; (9) the leached nature and the inadequate use of the soil could be dramatically accelerate soil degradation; (10) laminar erosion is potentially low in $3 / 4$ of the area adjacent to due to the landscape conformation and the presence of preserved vegetation while only $1 / 4$ of the area show medium to high erosion potential; (11) linear erosion is potentially low in $90 \%$ of the area around the reservoir; (12) the fertility analyses and the agroforestry experiments showed that mixtures formed by the sediments, crushed rocks and manure had the best response to remineralize the local soils; (13) experiments with agricultural, leguminous and forest species, presented a much faster and robust development when compared to the control parcel.

Integrating Earth and Life sciences information such as geochemical and soil fertility analyses plus a follow-up of agro-forest field trials was the interdisciplinary recommended approach the authors found to address complex environmental impacts caused by dams in forested areas inhabited by traditional people. It was found that the combined use of reservoir sediments, local available rocks and manure was an efficient, inexpensive way to restore soil fertility to be used in local agriculture and to bring back a healthy vegetation cover where life could again thrive. Solutions to similar problems must be creative and go beyond orthodox agro-economic approaches.

\section{ACKNWOLEDGMENTS}

The authors would like to thank Centrais Elétricas do Norte/Brazil for the financial support which allowed the realization of the Project, through the ANEEL edict, 2003/2004 cycle.

\section{RESUMO}

Este estudo sugere o emprego dos sedimentos acumulados no reservatório de Tucuruí (Pará/Brasil) para remineralizar os solos degradados do seu entorno. A abordagem foi baseada nos princípios da tecnologia da Rochagem. Isto sugere que o solo pode ser rejuvenescido pela adição de rochas moídas ricas em macro e micronutrientes. A remoção dos sedimentos para uso agrícola trará benefícios para os agricultores familiares da região, além de facilitar o aumento da vida útil do Reservatório e, portanto, da geração da energia. Dados geoquímicos dos sedimentos retidos, de solos e de rochas da área de influência do Reservatório foram avaliados no que diz respeito aos mecanismos de transporte e do potencial de nutrientes para fertilizar os solos. Os resultados mostram que os sedimentos do reservatório contêm níveis de nutrientes de no mínimo um grau de grandeza superior à média dos solos da Amazônia. Nossos dados produzidos nesta pesquisa sobre uso e ocupação do solo na região mostram as áreas degradadas que poderão ser recuperados pela técnica da Rochagem. Para comprovar os efeitos da remineralização dos solos foi instalado um Sistema Agroflorestal, com 12 parcelas onde diferentes misturas de sedimentos retirados do reservatório foram utilizadas juntamente com rocha moída com ou sem a adição de NPK e de composto orgânico. Os testes mostraram que a melhor produtividade agrícola e de crescimento das plantas foram obtidos nas parcelas onde a mistura de sedimentos, rochas moídas e composto orgânico foram adicionados.

Palavras-chave: geoquímica, sedimentos, reservatório, sistema agroflorestal, desenvolvimento sustentável.

\section{REFERENCES}

BRASIL. 2004. CPRM - Carta do Brasil ao Milionésimo.

CAmpangnoli F. 2002. A Aplicação do Assoreamento na Definição de Geoindicadores Ambientais em Áreas Urbanas: Exemplo na Bacia do Alto Tietê, SP. Tese de Doutorado. Escola Politécnica da Universidade de São Paulo, Dep. de Engenharia Hidráulica e Sanitária, São Paulo SP, 192 p. 
FonseCA R, BARRIGA FJAS, THEODORO SH, CANÁRIO T AND Morais M. 2007. The Três Marias reservoir, a sink for sediments outcoming from over-erosion of soils in Minas Gerais, Brazil. In: Sobral M and Gunkel G (Eds), Reservoirs and River Basins Management. Technical University of Berlin, p. 182-196.

IPT - Instituto DE PESQuisas TeCNOlógicas do Estado DE SÃo PAUlo. 1990. Orientaçõespara o Combate à Erosão no Estado de São Paulo, Bacia do Pardo Grande. São Paulo, 3v. (IPT. Relatório) 28: 184.

Kronberg BI, LeOnardos OH And Fyfe WS. 1987. The chemistry of some Brazilian soils element mobility during intense weathering. Chem Geol 60: 361-370.

LeONARdos OH, Fyfe WS AND KRONBERG BI. 1976. Rochagem: O método de aumento da fertilidade em solos lixiviados e arenosos. Anais 29 Congresso Brasil. Geol., Belo Horizonte, p. 137-145.

LEONARDOS OH AND THEODORO SH. 1999. Fertilizing tropical soils for sustainable development. In: Formoso MLL and Cerri CC (Eds), Proceedings International Workshop on Tropical Soils, Rio de Janeiro. An Acad Bras Cienc, p. 143-153.

LEONARDOS OH, THEODORO SH AND ASSAD ML. 2000. Remineralization for sustainable agriculture: A tropical perspective from a Brazilian viewpoint. In: Nutrient Cycling in Agroecosystms. Formerly Fertilizer Research. Holland 56: 3-9.

MACÊDO IL, THEOdoro SH, HernandeZ HMO AND CAMPAGNOLi F. 2007. Assessment of soil loss via laminar and linear erosion in the influence area of Tucuruí hydroelectric power station reservoir, Brazil. In: Off-Site Impacts of Soil Erosion and Sediment Transport. Prague. Czech Republic. http://storm.fsv.cvut.cz/cost634/20071003_cost634/index.html.

MAYER LD AND WISCHMEIER WH. 1969. Mathematical simulation of the process of soil erosion by water: Trans Am Soc Agric Eng 12: 754-758.
Merten GH, Caviglione JH, Ciacomini DC, Rufino RL, Medeiros G, Saintraint D, Ribas GC, Dedecek R AND KESSLER CA. 1995. El uso del SIG del modelo USLE para determinar mapas de erosion potencial y actual en las microcuencas pilotos de Água Grande y Córrego do Pensamento, Mamborê, Paraná, Brasil. Santiago, Chile: Proyeto Regional GCP/RLA/107/JPN, 43 p.

Rocha EL AND THEODORO SH. 2006. Fertilização organomineral para acelerar o desenvolvimento de agroflorestas sucessionais In: Botelho Fo, FB. Complexo Agroindustrial e outros estudos. Universidade de Brasília/CEAM/NEAGRI 6(26): 231-245.

TASSINARI CCG AND MACAMBIRA MJB. 1999. Geochronological Provinces of the Amazonian Craton. Episodes 22: $174-182$.

THEOdoro SH. 2000. A Fertilização da Terra pela Terra: Uma Alternativa de Sustentabilidade para o Pequeno Produtor Rural. (Ph.D. Thesis, Universidade de Brasilia, 231 p. http://www.unbcds.pro.br/publicacoes/SuziHuff.pdf

THEODORO SH, FONSECA RM, BARRIGA FJAS, MACEDO IL AND MORAIS MM. 2007. The use of accumulated sediments in the Tucuruí and Três Marias dams to recover degraded soils In: Gunkel G and Sobral MC (Eds), Reservoirs and River Basins Management: Exchange of Experience from Brazil, Portugal and Germany, p. 211-225.

Theodoro SH AND LeONARdos OH. 2006. Sustainable farming with native rocks: the transition without revolution. An Acad Bras Cienc 78: 715-720.

Trouw RAJ, VAZ LF, SLONGO TT AND NAKASATO N. 1976. Geologia da Região de Tucuruí, Baixo Tocantins, Pará. XXIX Congresso de Geologia. Ouro Preto/MG, Brasil 2: 137-148.

VAn StraAten P. 2007. Agrogeology: The use of rock for crops Enviroquest Ltd., 440 p. 